\title{
PENGARUH PENGGUNAAN SCHOOLOGY DALAM MODEL BELAJAR LEARNING CYCLE 6 FASE-PROBLEM SOLVING (LC 6F-PS) TERHADAP PEMAHAMAN KONSEPTUAL DAN GRAFIK PADA MATERI LAJU REAKSI
}

\author{
Reny Eka Evi Susanti ${ }^{1}$, Srini M. Iskandar ${ }^{2}$ \\ ${ }^{1}$ Kimia, Universitas PGRI Banyuwangi, Jawa Timur, Indonesia \\ ${ }^{2}$ Pendidikan Kimia, Universitas Negeri Malang, Jawa Timur, Indonesia
}

\section{A R T I C L E I N F O}

Article history:

Received 18 September 2019

Received in revised form

1 October 2019

Accepted 4 October 2019

Available online 12 October 2019

Kata Kunci:

Pemahaman konseptual,

Pemahaman grafik

Laju reaksi,

Schoology,

Learning cycle 6F-Problem Solving

\begin{abstract}
A B S T R A K
Tujuan penelitian ini adalah (1) untuk mengetahui pengaruh penggunaan schoology dalam model belajar learning cycle 6Fproblem solving terhadap pemahaman konseptual dan grafik siswa pada materi laju reaksi dan (2) mengetahui apakah ada hubungan antara pemahaman monseptual dengan pemahaman grafik siswa pada materi laju reaksi. Penelitian ini menggunakan rancangan penelitian eksperimental semu postest only design. Populasi penelitian adalah siswa kelas XI MIPA SMA Negeri 1 Genteng. Sampel yang digunakan yaitu kelas XI MIPA 4 sebagai kelas eksperimen dan XI MIPA 5 sebagai kelas kontrol. Pengujian hipotesis dianalisis menggunakan uji $t$ dan uji korelasi dengan taraf signifikansi $\alpha=0,05$. Hasil penelitian menunjukkan (1) ada perbedaan yang signifikan tingkat pemahaman konseptual dan grafik siswa yang dibelajarkan dengan menggunakan aplikasi schoology dalam model belajar learning cycle 6F-problem solving dengan siswa yang dibelajarkan menggunakan model belajar learning cycle 6F-
\end{abstract} problem solving dan (2) tidak ada hubungan signifikan ntara tingkat pemahaman konseptual dengan pemahaman algoritmik siswa.

\section{ABSTRACT}

The purposes of the research were (1) to find out the effect of schoology use in six phased learning cycle-problem solving toward the student's conceptual and graphical understanding on the reaction rate, and (2) to find out the correlation between student's conceptual undertanding with graphical understanding on the reaction rate. The design of the research was quasy experimentpostest-only design. The population in this research was grade XI of Senior High School 1 Genteng. The sample which were chosen using cluster random sampling were XI MIPA 4 as an experimental class, XI MIPA 5 as the control class.The hypothesis testing was performed by t-test and correlation test using SPSS 16 for windows with a significance level $\alpha=0,05$. The result of the research showed that there were (1) significant differences of conceptual, algorithmic, and graphical understanding between students who learned using the applied schoology use in six phased learning cycle-problem solving and the students who learned using the six phased learning cycle-problem solving. (2) there was between student's conceptual understanding with graphical undertanding.

\footnotetext{
1 Corresponding author.

E-mail : renyekaevisusanti@gmail.com, iskandar.srini45@gmail.com
} 


\section{PENDAHULUAN}

Kimia menurut Efendi (2008:1) adalah cabang IPA yang mempelajari tentang komposisi materi, struktur materi, perubahan materi, hukum dasar, serta konsep dan teori yang menjelaskan perubahan materi tersebut.Dalam mengajarkan ilmu kimia pada kurikulum 2013 seorang guru mempunyai tantangan yang sangat besar yaitu materi kimia yang bersifat abstrak dan banyak harus dibelajarkan dalam waktu yang relatif singkat. Berdasarkan sudut pandang peserta didik mempelajari ilmu kimia terkesan sulit karena mempelajari kimia sama halnya mempelajari bahasa yang baru (Chang, 2004:4) dan perhitungan dalam kimia merupakan perhitungan matematika yang tidak sederhana (Nazriati \& Fajaroh, 2007:168). Konsep-konsep ilmu kimia bersifat abstrak misalnya ion, orbital, molekul, entalpi dan entropi. Adanya keterbatasan waktu yang tersedia, seorang guru cenderung hanya mentransfer pengetahuan untuk mengejar target kurikulum, namun tidak mempelajari konsep ilmu kimia secara mendalam. Dampak dari pembelajaran untuk memenuhi target kurikulum yaitu peserta didik tidak dapat menyadari bahwa ilmu kimia sangat penting untuk dipahami sebagai pengetahuan dasar untuk memecahkan suatu masalah dalam kehidupan sehari-hari (Fajaroh \& Dasna, 2004:112). Sehingga dalam lingkungan SMA peserta didik mempelajari ilmu kimia hanya dikarenakan kimia merupakan matapelajaran wajib yang harus ditempuh bukan karena kimia sangat penting bagi kehidupan seharihari.

Laju reaksi merupakan salah satu materi kimia yang dibelajarkan di SMA yang mempunyai konsep-konsep penting untuk memahami fenomena kimia yang terjadi dalam kehidupan sehari-hari serta menjelaskan mengapa fenomena tersebut terjadi (Kolomuc \& Tekin, 2001:85).Bagi peserta didik laju reaksi merupakan salah satu pelajaran yang terkesan sulit, kesulitan tersebut dikarenakan dalam materi laju reaksi terdapat materi yang bersifat konseptual, algoritmik dan grafik.Sebagai contoh pada konsep orde reaksi, materi penentuan orde reaksi berdasarkan data percobaan merupakan tinjauan aspek algoritmik, materi grafik hubungan laju reaksi terhadap konsentrasi berdasar orde reaksi merupakan tinjauan aspek grafik, dan konsep tentang orde itu sendiri merupakan tinjauan aspek konseptual.

Sebagian besar tingkat pemahaman algoritmik peserta didik lebih tinggi dibandingkan dengan tingkat pemahaman konseptual dan grafik (Costu, 2010). Rendahnya Pemahaman Konseptual dan grafik dibandingkan pemahaman algortimik disebabkan oleh beberapa hal diantaranya (1) peserta didik tidak mempunyai kesempatan untuk mengkonstruk pengetahuan secara mendalam, (2) model pembelajaran yang diterapkan pengajar lebih menekankan pada latihan soal yang bersifat hitungan, dan (3) pemahaman algoritmik lebih cepat dan mudah dikuasai peserta didik dibandingkan pemahaman konseptual dan pemahaman grafik (Anderson dalam Chiu, 2001:20). Kesulitan peserta didik dalam mempelajari laju reaksi diperjelas berdasarkan dari hasil wawancara dengan salah satu guru kimia SMA Negeri 1 Genteng dan diperoleh informasi bahwa (1) peserta didik mengalami kesulitan dalam menjelaskan hubungan laju reaksi dengan waktu dan menggambarkan grafik hubungan keduanya, (2) menghubungkan pengaruh faktor luas permukaan bidang sentuh dengan teori tumbukan, dan (3) penggambaran grafik orde reaksi.

Untuk mengetahui kondisi yang sebenarnya maka peneliti melakukan observasi pada dua sekolahan di Banyuwangi yaitu SMA Negeri 1 Genteng dan SMA Negeri 2 Genteng dan hasil observasinya adalah metode belajar yang digunakan untuk membelajarkan materi laju reaksi adalah metode ceramah, tanya jawab dan latihan soal (dokumen pribadi, 2013). Implementasi dari penerapan ketiga metode belajar tersebut menyebabkan peserta didik cenderung pasif, jarang bertanya kepada guru dan hanya mencatat penjelasan yang diberikan oleh guru.Hal tersebut menunjukkan bahwa keaktifan belajar peserta didik kurang.

Berdasarkan permasalahan tersebut diatas diperlukan adanya penerapan metode pembelajaran yang berbasi konstuktivistik. Salah satu pembelajaran berbasis konstruktivistik yang sesuai untuk membelajarkan materi laju reaksi yaitu learning Cycle 6 Fase - Problem Solving (LC6F-PS). Learning cycle 6 Fase terdiri atas fase identification, engagement, exploration, explanation, elaboration, evaluation.Dalam pembelajaran learning cycle 6 fase-problem solving, pembelajaran problem solving dimunculkan saat kegiatan learning cycle 6 fase pada fase elaboration. Pada fase elaboration peserta didik melakukan aktifitas menerapkan konsep dan ketrampilan dengan bantuan pertanyaan yang sifatnya menuntun sesuai dengan langkah-langkah pembelajaran problem solving, yang bertujuan untuk memperkuat konsep yang sudah terbangun. Menurut teori belajar konstruktivistik, walaupun tanggungjawab peserta didik adalah belajar dan memahami apa yang terjadi, peserta didik juga perlu waktu untuk mengalami, merefleksi pengalaman dikaitkan dengan pengetahuan awal dan memecahkan masalah yang muncul (Rahayu, Prayitno \& Fajaroh, 2008: 126). Oleh karena itu penerapan problem solving dalam fase elaboration akan memberi peluang bagi setiap siswa untuk 
mengklarifikasi, mengelaborasi, mendeskripsikan dan membandingkan konsep awal yang telah dikonstruksi dalam pikirannya untuk memperoleh keputusan tentang berlaku tidaknya konsep tersebut.Pemilihan metode pembelajaran learning Cycle 6 Fase - Problem Solving (LC6F-PS) berdasarkan karakteristik materi laju reaksi itu sendiri yaitu konseptual dan perhitungan kimia.

Dalam mengatasi keterbatasan waktu dalam membelajarkan materi kimia dapat menggunakan pembelajaran online dengan bantuan situs Schoology.Schoology merupakan situs yang menggabungkan fitur jejaring sosial dan LMS (Learning Management Sistem). Kelebihan schoology, yaitu: (1) peserta didik dengan mudah menjelajah fitur-fitur yang ada di schoology karena hampir sama dengan jejaring sosial lainnya misalnya facebook, (2) fitur-fitur dalam shoology difokuskan pada proses pembelajaran yaitu tersedianya fasilitas absensi, fasilitas analytic digunakan untuk melihat aktivitas peserta didik, pengumpulan tugas, diskusi dll, (3) schoology dilengkapi dengan symbol, equation dan latex yang mendukung untuk pembuatan soal yang membutuhkan simbol-simbol matematika, (4) schoology dapat mengirim audio dan video, (5) schoology tersedia dalam bentuk mobile learning yang dapat di unduh melalui play store (Biswas, 2013). Penggunaan schoology dalam pembelajaran tersebut sesuai dengan penerapan kurikulum 2013, yaitu setiap matapelajaran harus terintegrasi dengan TIK.

Berdasarkan dari uraian diatas, maka peneliti melakukan untuk mengetahui pengaruh penggunaan schoology dalam model belajar learning Cycle 6 Fase - Problem Solving terhadap pemahaman konseptual dan pemahaman grafik pada materi laju reaksi. Pembelajaran laju reaksi dibelajarkan dengan dua tahap yaitu offline dan online, pada saat offline peserta didik mengggunakan metode belajar learning Cycle 6 Fase - Problem Solving, dan dilanjutkan pembelajaran secara online diluar jam pelajaran melalui diskusi dengan menggunakan situs schoology.

\section{METODE}

Sesuai dengan tujuan penelitian yang diinginkan yaitu untuk mengetahui pengaruh penggunaan schoology dalam model belajar Learning Cycle 6 Fase - Problem Solving (LC6F-PS) terhadap pemahaman konseptual dan pemahaman grafik pada materi laju reaksi, maka penelitian ini menggunakan jenis rancangan penelitian eksperimental semu posttest-only design. Bagan rancangan penelitian dapat dilihat pada Tabel 1 berikut.

Tabel 1.

Rancangan Penelitian

\begin{tabular}{lcccc}
\hline \multicolumn{1}{c}{ Kelas } & Kemampuan & Perlakuan & Penguasaan Kompetensi \\
& Awal & & $\mathrm{X}$ & 0 \\
\hline Eksperimen & - & - & 0 \\
Kontrol & - & & 0 \\
\hline
\end{tabular}

(Creswell, 2002:310)

Keterangan :

$\mathrm{X}=$ Pembelajaran menggunakan Schoologydalam model belajar learning cycle 6 fase-problem solving $\mathrm{O}=$ post test

Populasi pada penelitian ini adalah semua peserta didik kelas XI MIPA SMA Negeri 1 Genteng yang terdiri atas lima kelas yaitu XI MIPA 1, XI MIPA 2, XI MIPA 3, XI MIPA 4 dan XI MIPA 5. Sampel dilakukan dengan teknik cluster random sampling, karena di SMAN 1 Genteng tidak ada perbedaan antara kelas unggulan dan tidak. Penentuan pengambilan sampel dilakukan dengan teknik undian dan akan memilih dua kelas dimana terpilih XI MIPA 4 digunakan sebagai kelas eksperimen yang dibelajarkan menggunakan schoology dalam model belajar learning cycle 6 fase-problem solvingdan XI MIPA 5 sebagai kelas control yang dibelajarkan menggunakan model belajar learning cycle 6 faseproblem solving.

Instrumen yang digunakan berupa (1) instrumen perlakuan meliputi silabus, RPP, LKS, dan bahan ajar, dan (2) instrumen pengukur meliputi soal test laju reaksi berbentuk pilihan ganda. Pengujian hipotesis penelitian dianalisis dengan menggunakan uji-t dan uji korelasidibantu program SPSS 16 for windows dengan taraf signifansi $\alpha=0,05$. Uji-t digunakan untuk mengetahui apakah ada perbedaan yang signifikan pemahaman konseptual dan grafik peserta didik yang dibelajarkan dengan schoology dalam model belajar learning cycle 6 fase-problem solving dengan peserta didik yang dibelajarkan dengan learning cycle 6 fase-problem solving. 


\section{HASIL DAN PEMBAHASAN \\ Hasil}

Uji awal yang dilakukan adalah uji kesamaan rata-rata yang bertujuan untuk mengetahui pengetahuan awal peserta didik antara peserta didik kelas eksperimen dan peserta didik kelas kontrol.Data pengetahuan awal peserta didik berasal dari nilai ulangan harian peserta didik pada materi hidrokarbon dan termokimia, hasilnya dapat dilihat pada Tabel 2.

Tabel 2.

Data Kemampuan Awal Siswa

\begin{tabular}{lcccc}
\hline Kelas & Jumlah Siswa & $\begin{array}{c}\text { Nilai } \\
\text { Tertinggi }\end{array}$ & Nilai Terendah & Nilai Rata-Rata \\
\hline Eksperimen & 39 & 85 & 65 & 73 \\
Kontrol & 38 & 84 & 68 & 73 \\
\hline
\end{tabular}

Berdasarkan Tabel 2 dapat dilihat bahwa rata-rata nilai ulangan harian antara peserta didik kelas eksperimen dengan peserta didik kelas kontrol adalah sama, yaitu 73. Salain menggunakan nilai rata-rata kemampuan awal rata-rata peserta didik dihitung dengan menggunakan uji normalitas, homogenitas dan uji kesamaan rata-rata. Hal ini bertujuan untuk memastikan apakah kedua kelas tersebut mempunyai tingkat rata-rata kemampuan awal sama atau tidak.

Tabel 3.

Hasil Uji Normalitas dan Uji Homogenitas

\begin{tabular}{llrc}
\hline \multicolumn{1}{c}{ Uji } & \multicolumn{1}{c}{ Kelas } & $\begin{array}{r}\text { Nilai } \\
\text { Signifikansi }\end{array}$ & Kesimpulan \\
\hline Uji & Eksperimen & 0,520 & Normal \\
Normalitas & Kontrol & 0,180 & Normal \\
\hline Uji & Eksperimen & 0,586 & Homogen \\
Homogenitas & Kontrol & & \\
\hline
\end{tabular}

Setelah ketiga uji tersebut dilakukan diperoleh hasil yaitu data terdistribusi normal dan homogen, selanjutnya dilakukan uji kesamaan rata-rata dengan menggunakan uji-t (program SPSS 16.0 for windows). Hasil uji-t dapat dilihat pada Tabel 4

Tabel 4.

Hasil Uji Kesamaan Rata-Rata Kemampuan Awal Siswa

\begin{tabular}{ccc}
\hline Kelompok & Sig. (2-tailed) & Kesimpulan \\
\hline Kemampuan Awal & 0,391 & Kemampuan awal siswa \\
sama \\
\hline
\end{tabular}

Berdasarkan data Tabel.4 diperoleh nilai signifikasi > 0,05, yang berarti sampel mempunyai rata-rata kemampuan awal sama.

Data tingkat pehaman konseptual dan pemahaman grafik peserta didik diperoleh dari nilai test akhir laju reaksi berbentuk pilihan ganda dengan nilai reliabilitas 0,917. Berdasarkan hasil test akhir laju reaksi diperoleh data rata-rata pemahaman konseptual dan pemahaman grafik peserta didik kelas eksperimen lebih tinggi dibandingkan peserta didik kelas kontrol. Nilai rata-rata pemahaman konseptual peserta didik kelas eksperimen adalah 7,2 dan peserta didik kelas kontrol adalah 6,4. Nilai rata-rata pemahaman grafik peserta didik kelas eksperimen adalah 6,0 dan peserta didik kelas kontrol adalah 4,9. Dari data tersebut selanjutnya nilai diolah dengan menggunakan uji-t yang sebelumnya dilakukan uji normalitas dan uji homogenitas dengan nilai signifikansi 0,05 yang dapat dilihat pada Tabel 5. 
Tabel 5.

Hasil Uji Normalitas dan Uji Homogenitas

\begin{tabular}{|c|c|c|c|c|}
\hline Uji & Aspek & Kelas & Nilai Signifikansi & Kesimpulan \\
\hline Uji & Konseptual & Eksperimen & 0,059 & Normal \\
\hline Normalitas & & Kontrol & 0,069 & Normal \\
\hline \multirow{4}{*}{$\begin{array}{l}\text { Uji } \\
\text { Homogenitas }\end{array}$} & Grafik & Eksperimen & 0,191 & Normal \\
\hline & & Kontrol & 0,167 & Normal \\
\hline & Konseptual & $\begin{array}{l}\text { Eksperimen } \\
\text { Kontrol }\end{array}$ & 0,586 & Homogen \\
\hline & Grafik & $\begin{array}{l}\text { Eksperimen } \\
\text { Kontrol }\end{array}$ & 0,458 & Homogen \\
\hline
\end{tabular}

Dari data diatas dapat diketahui bahwa pemahaman konseptual dan pemahaman grafik peserta didik terdistribusi normal dan homogen. Selanjutnya dilakukan uji hipotesis menggunakan independent-sampel t test dan hasilnya dapat dilihat pada Tabel 6.

Tabel 6.

Hasil Uji Hipotesis

\begin{tabular}{cccc}
\hline Aspek & Kelompok & Sig. (2-tailed) & Kesimpulan \\
\hline Konseptual & Hasil Belajar & 0,001 & Ho ditolak \\
Grafik & Hasil Belajar & 0,003 & Ho ditolak \\
\hline
\end{tabular}

Berdasarkan Tabel 6 nilai signifikansi pada aspek pemahaman konseptual kurang dari 0,05 (yaitu 0,001) dan pada aspek pemahaman grafik nilai signifikansi kurang dari 0,05 (yaitu 0,003), sehingga dapat disimpulkan bahwa terdapat perbedaan yang signifikan pemahaman konseptual dan pemahaman grafik peserta didik yang dibelajarkan dengan schoology dalam model belajar learning cycle 6 fase-problem solving dengan peserta didik yang dibelajarkan dengan learning cycle 6 faseproblem solving pada materi laju reaksi.

Untuk mengetahui apakah tingkat pemahaman konseptual peserta didik saling berhubungan atau tidak dengan tingkat pemahaman grafik maka dilakukan uji korelasi. Uji ini korelasi yang digunakan menggunakan bantuan program SPSS 16.0 for windows pearson correlation pada taraf signifikansi 5\%. Pengambilan keputusan apabila nilai signifikansinya $<\alpha$ (nilai signifikansi 5\%) maka ada hubungan antara pemahaman konseptual dengan pemahaman grafik siswa.

Tabel 7.

Hasil Uji Korelasi antara Pemahaman Konseptual dengan Pemahaman Grafik Peserta Didik

\begin{tabular}{lcc}
\hline Kelompok & $\begin{array}{c}\text { Sig. (2- } \\
\text { tailed) }\end{array}$ & Kesimpulan \\
\hline Eksperimen & 0.848 & Tidak ada hubungan \\
Kontrol & 0,726 & Tidak ada hubungan \\
\hline
\end{tabular}

\section{Pembahasan}

Pelaksanaan pembelajaran mengacu pada RPP learning cycle 6 fase-problem solving yang telah dibuat. Tiap pertemuan tatap muka terdiri dari tiga bagian, antara lain kegiatan pendahuluan, kegiatan inti, dan kegiatan penutup. Kegiatan pendahuluan diawali dengan memaparkan tujuan pembelajaran (fase identifikasi), kegiatan pendahuluan bertujuan agar peserta didik mengetahui kompetensi dasar yang harus dikuasai oleh peserta didik setelah pembelajaran berakhir (Iskandar, 2011:49).Kegiatan inti meliputi beberapa fase yaitu engagement, exploration, explanation, dan elaboration (pada fase ini menerapkan metode belajar problem solving).Kegiatan penutup guru membimbing peserta didik menyimpulkan materi yang telah dipelajari, kemudian memberikan post test (fase evaluation).Tahaptahap pembelajaran hasil modifikasi pembelajaran learning cycle 6 fase-problem solving dapat dilihat pada gambar 1 . 


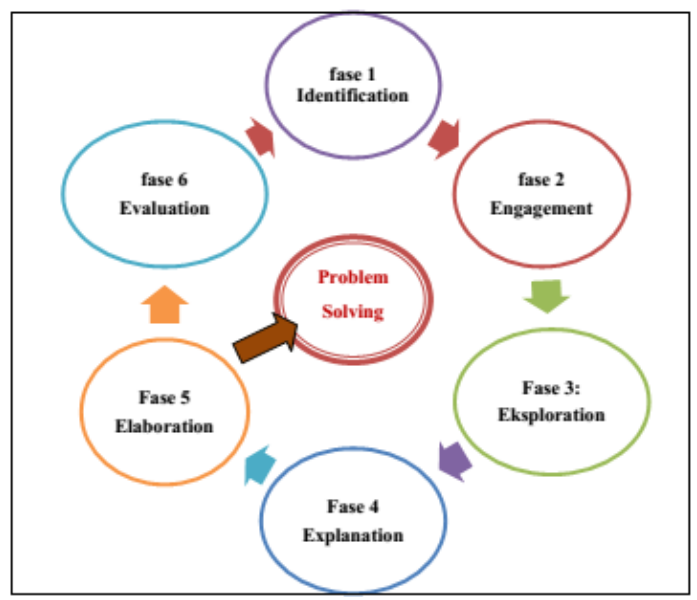

Gambar 1. Diagram Tahapan Pembelajaran Perpaduan Pembelajaran learning cycle 6 faseproblem solving

\section{Identification}

Pada fase identifikasi guru menyampaikan tujuan pembelajaran. Tujuan pembelajaran pada pertemuan pertama adalah menjelaskan pengertian laju reaksi, dan menentukan laju reaksi tiap-tiap zat, pertemuan kedua yaitu faktor yang mempengaruhi laju reaksi (luas permukaan dan konsentrasi), pertemuan ketiga yaitu faktor yang mempengaruhi laju reaksi (temperatur dan katalis), pertemuan keempat yaitu tentang teori laju reaksi, dan pertemuan kelima yaitu menentukan hukum laju dan orde reaksi.

\section{Engagement}

Pada fase engagement guru mengajukan pertanyaan undangan untuk peserta didik, hal ini bertujuan untuk melihat pengetahuan awal peserta didik serta mengetahui kesalahan konsep pada pembelajaran sebelumnya (Fajaroh \& Dasna, 2007: 97). Selain hal tersebut pada fase ini seorang guru membangkitkan minat dan keingintahuan peserta didik tentang topik yang akan diajarkan. Pada pertemuan pertama mempunyai dua siklus yaitu (a) apa yang anda ketahui tentang pengertian laju rekaksi berdasarkan grafik penguraian gas dinitrogen pentaoksida?, (b) apa yang anda ketahui tentang laju reaksi masing-masing zat dan laju reaksi secara umum pada reaksi pembakaran buatana?. Sehubungan strategi pembelajaran merupakan hal baru bagi peserta didik, sehingga pelaksanaan pembelajaran pada pertemuan pertama tidak sesuai dengan waktu yang direncanakan.

Pada pertemuan ke dua terdapat dua siklus juga yaitu (a) apa yang anda ketahui tentang pengaruh luas permukaan bidang sentuh suatu partikel terhadap laju reaksi?, (b) apa yang anda ketahui tentang pengaruh konsentrasi terhadap laju reaksi?. Pertemuan ke tiga mempunyai dua siklus yaitu (a) apa yang anda ketahui tentang pengaruh temperatur terhadap laju reaksi?, (b)apa yang anda ketahui tentang pengaruh katalis terhadap laju reaksi?. Pertemuan keempat terdapat satu siklus yaitu apa yang anda ketahui tentang terjadinya suatu reaksi berdasarkan teori tumbukan dan teori keadaan transisi?. Pada pertemuan kelima terdapat tiga siklus yaitu (a) apakah yang anda ketahui apakah yang anda ketahui tentang persamaan laju reaksi untuk reaksi $\mathrm{mA}+n B \rightarrow$ produk?", (b) apa yang anda ketahui tentang hukum laju berdasarkan mekanisme reaksi penentu laju?, (c) apa yang anda ketahui tentang grafik laju reaksi orde 0 , orde 1 dan orde 2 ?.

\section{Exploration}

Pada fase eksplorasi guru memberikan pertanyaan "apakah jawaban yang anda tuliskan benar atau salah?".Untuk membuktikan jawaban peserta didik benar atau salah guru membimbing peserta didik membuka bahan ajar dan literatur llain yang relevan, selain literatur bisa juga dengan praktikum yang dilaksanakan pada pertemuan ketiga dan pertemuan keempat. 


\section{Explanation}

Pada fase ini guru memberikan pertanyaan kepada peserta didik yaitu "dapatkah kalian memberikan penjelasan mengapa jawaban kalian benar atau salah?".Pada tahap ini peserta didik dituntun untuk menjelaskan konsep dengan kalimat mereka sendiri dan disertai dengan literatur yang jelas.

\section{Elaboration}

Pada fase elaborasi peserta didik diberikan beberapa pertanyaan dan penyelesaiannya peserta didik dituntun menggunakan tahap pembelajaran problem solving, yaitu (1) pemahaman masalah, guru menanyakan kepada peserta didik informasi apa saja yang terdapat dalam soal tersebut?, dan meminta salah satu peserta didik untuk mengutarakan jawabannya, (2) pembuatan rencana penyelesaian masalah, guru meminta setiap kelompok berdiskusi bagaimana cara menyelesaikan soal tersebut, kemudian meminta perwakilan kelompok untuk mengutarakan jawabannya, (3) pelaksanaan rencana penyelesaian masalah, meminta setiap kelompok menyelesaikan soal terebut, (4) pemeriksaan kembali, guru meminta setiap kelompok untuk mengoreksi kembali setiap langkah yang dilakukan serta jawaban hasil diskusi, dan perwakilan setiap kelompok mempresentasikan hasil diskusi didepan kelas.

\section{Evaluation}

Fase evauasi dilakukan disetiap akhir pembelajaran dan bersifat individu.Hal ini bertujuan untuk mengetahu pemahaman setiap peserta didik tentang materi yang telah dibahas pada setiap pertemuan.

Langkah-langkah hasil modifikasi pembelajaran learning cycle 6 fase-problem solving dapat dilihat pada Tabel 8 .

Tabel 8.

Rancangan Tahapan Pelaksanaan Pembelajaran learning cycle 6 fase-problem solving

\begin{tabular}{|c|c|}
\hline $\begin{array}{c}\text { Tahapan } \\
\text { Pembelajaran }\end{array}$ & $\begin{array}{c}\text { Kegiatan Pembelajaran } \\
\text { "offline" }\end{array}$ \\
\hline $\begin{array}{l}\text { Kegiatan } \\
\text { Pendahuluan }\end{array}$ & $\begin{array}{l}\text { - Membuka pelajaran dengan salam } \\
\text { - Meminta ketua kelas untuk memimpin doa } \\
\text { - Memeriksa kehadiran peserta didik } \\
\text { - Mengkomunikasikan tujuan pembelajaran } \\
\text { - Memberikan Lembar Kerja Siswa (LKS) } \\
\text { - Mengulas sedikit materi tentang reaksi contoh reaksi cepat dan reaksi lambat }\end{array}$ \\
\hline \multirow[t]{3}{*}{ Kegiatan Inti } & $\begin{array}{l}\text { Fase 2: Undangan (Engagement) } \\
\text { - Memberi pertanyaan kepada mahasiswa } \\
\text { "Apa yang Anda ketahui tentang ......" } \\
\text { - Memberi kesempatan kepada peserta didik untuk menuliskan jawaban pada } \\
\text { Lembar Kerja Siswa (LKS) }\end{array}$ \\
\hline & $\begin{array}{l}\text { Fase 3: Eksplorasi (Exploration) } \\
\text { - Memberikan pertanyaan kepada peserta didik } \\
\text { "Apakah jawaban Anda benar, setengah benar, atau salah? Silahkan Anda } \\
\text { mencari dari berbagai sumber" } \\
\text { - Memberi kesempatan kepada peserta didik untuk mencari informasi dari } \\
\text { berbagai sumber dan menuliskan jawaban pada Lembar Kerja Siswa (LKS) }\end{array}$ \\
\hline & $\begin{array}{l}\text { Fase 4: Penjelasan (Explanation) } \\
\text { - Memberikan pertanyaan kepada peserta didik } \\
\text { "Berikan alasan mengapa jawaban Anda benar, setengah benar, atau } \\
\text { salah?" } \\
\text { - Memberi kesempatan kepada peserta didik untuk menuliskan jawaban pada } \\
\text { Lembar Kerja Siswa (LKS) }\end{array}$ \\
\hline
\end{tabular}




\section{Fase 5: Penerapan (Elaboration)}

- Membagi peserta didik dalam 8 kelompok, masing-masing kelompok terdiri dari 5 anggota.

- Memberikan soal latihan untuk dikerjakan masing-masing kelompok

- Membimbing mahasiswa memecahkan soal latihan

1. Pemahaman masalah

- menanyakan informasi apa saja yang terdapat dalam soal

- meminta salah satu siswa untuk mengungkapkan informasi yang didapat dari soal

2. Pembuatan rencana penyelesaian masalah

- meminta setiap kelompok untuk berdiskusi bagaimana cara pemecahan soal tersebut

- meminta salah satu peserta didik untuk mengungkapkan cara pemecahan masalah

3. Pelaksanaan rencana penyelesaian masalah

- meminta setiap kelompok berdiskusi penyelesaian soal

- mengamati jalannya diskusi kelompok

4. Pemeriksaan kembali

- meminta setiap kelompok mengecek kembali setiap langkah yang dilakukan serta jawaban hasil diskusi

- Meminta beberapa perwakilan kelompok untuk mempresentasikan hasil pemecahan soal

- Membimbing peserta didik membuat

Kegiatan Fase 6: Evaluasi (Evaluation)

Penutup - Memberikan tes untuk dikerjakan secara individu

- Meminta ketua kelas untuk membantu mengumpulkan jawaban peserta didik

- Mengingatkan materi pertemuan selanjutnya

- Menutup pelajaran dengan salam

Pengunaan schoology digunakan sebagai alat bantu diskusi diluar jam pembelajaran secara online.Dalam hal ini guru memberikan tugas kepada peserta didik, pada kelas eksperimen tugas didiskusikan berkelompok secara online menggunakan aplikasi schoology sedangkan pada kelas kontrol tugas didiskusikan diluar jam pembelajaran tatap muka dengan teman satu kelompoknya.

Sebelum melaksanakan treatment pembelajaran, terlebih dahulu menguji kemampuan awal peserta didik antara kelas eksperimen dan kelas kontrol.Data kemampuan awal peserta didik diambil dari nilai ulangan harian pada materi sebelumnya yaitu hidrokarbon dan termokimia. Berdasarkan data yang diperoleh nilai rata-rata antara peserta didik kelas eksperimen dan kelas kontrol adalah sama yaitu 73, sehingga dapat disimpulkan bahwa tidak ada perbedaan kemampuan peserta didik antara kelas eksperimen dan kelas kontrol. Selain dilihat dari rata-rata nilai, kemampuan awal peserta didik dihitung juga dengan menggunakan uji normalitas, homogenitas dan uji kesamaan rata-rata.Dari ketiga uji tersebut diperoleh bahwa nilai kemampuan awal siswa terdistribusi normal dan homogen.Uji kesamaan rata-rata menggunakan uji-t dan menunjukkan nilai signifikansi sebesar 0,391 yang berarti tidak ada perbedaan nilai kemampuan awal peserta didik antara kelas eksperimen dan kelas kontrol. Setelah mengetahui kemampuan awal peserta didik yang sama, selanjutnya diberikan perlakuan yang berbeda dalam membelajarkan laju reaksi yaitu peserta didik kelas ekperimen dibelajarakan dengan menggunakan schoology dalam model belajar learning cycle 6F-problem solving sedangkan peserta didik kelas kontrol dibelajarkan dengan menggunakan model belajar learning cycle 6F-problem solving.

Laju reaksi merupakan salah satu materi kimia yang diajarkan dalam pembelajaran SMA kelas XI.Selain aspek algoritmik atau biasa disebut aspek hitungan dalam mempelajari laju reaksi peserta didik juga dituntut memahami aspek konseptual dan aspek grafik. Data tingkat pemahaman konseptual dan pemahaman grafik peserta didik diperoleh dari nilai test akhir laju reaksi berbentuk pilihan ganda. Hasil test akhir peserta didik kelas yang dibelajarkan dengan schoology dalam model belajar learning cycle 6 fase-problem solving lebih tinggi dibandingkan dengan peserta didik yang dibelajarkan dengan learning cycle 6 fase-problem solving pada materi laju reaksi. Pengujian nilai akhir test menggunakan SPSS 16.0 for Widows dengan uji independent-sample t test diperoleh nilai signifikansi pada aspek pemahaman konseptual kurang dari 0,05 (yaitu 0,001) dan pada aspek 
pemahaman grafik nilai signifikansi kurang dari 0,05 (yaitu 0,003), sehingga dapat disimpulkan bahwa terdapat perbedaan yang signifikan pemahaman konseptual dan pemahaman grafik peserta didik yang dibelajarkan dengan schoology dalam learning cycle 6 fase-problem solving dengan peserta didik yang dibelajarkan dengan learning cycle 6 fase-problem solving pada materi laju reaksi.

Pemahaman konseptual dan pemahaman grafik peserta didik yang dibelajarkan dengan schoology dalam model belajar learning cycle 6 fase-problem solving lebih tinggi dibandingkan peserta didik yang dibelajarkan dengan learning cycle 6 fase -problem solving. Hal tersebut dikarenakan dengan diterapkannya schoology peserta didik dapat lebih aktif dan interaktif, hal ini dapat dilihat dari (1) keaktifan peserta didik dalam chat dan mengumpulkan tugas, (2) apabila ada peserta didik kurang paham dengan materi ataupun tugas yang diberikan, peserta didik tersebut tidak malu bertanya langsung dengan peneliti melalui chat atau pesan tanpa harus bertatap muka, (3) peserta didik termotivasi untuk belajar karena senang melaksanakan pembelajaran online yang merupakan pengalaman baru melaksanankan pembelajaran diluar kelas, (4) peserta didik dapat memperoleh banyak sumber yang berhubungan dengan materi tidak hanya berasal dari peneliti tetapi dari sumber internet lainnya. Hal ini diperkuat oleh Dzuban (2004) dan Staker \& Hom (2012: 3) menyatakan bahwa dengan pembelajaran blended learning (perpaduan pembelajaran tatap muka dan online) peserta didik menjadi lebih aktif, meningkatkan interaksi antara guru dengan peserta didik, dan mengatasi keterbatasan waktu karena pembelajaran dapat dilakukan dimana saja dan kapan saja.

Dalam menentukan apakah ada hubungan atau tidak antara pemahaman konseptual dengan pemahaman grafik, maka diperlukan uji korelasi. Berdasarkan hasil analisis data dengan menggunakan uji pearson correlation diperoleh nilai signifikansi lebih dari 0,05 pada kelas eksperimen dan kelas kontrol, sehingga dapat disimpulkan bahwa tingkat pemahaman konseptual dan tingkat pemahaman grafik peserta didik tidak saling berhubungan. Peserta didik yang mempunyai tingkat pemahaman konseptual yang baik belum tentu tingkat pemahaman grafiknya baik pula.Tingkat pemahaman grafik peserta didik lebih rendah dengan tingkat pemahaman konseptual peserta didik, hal ini selaras dengan penelitian costu (2010) dan Kurnaz (2013). Pemahaman grafik lebih rendah disebabkan beberapa hal yaitu (1) sebagian besar peserta didik masih belum maksimal dalam mengkonstruk dan menginterpretasikan grafik dengan benar berdasarkan pemahaman konseptual yang dimiliki, (2) peserta didik belum terbiasa dengan adanya penekanan pemahaman grafik dalam pembelajaran kimia, dan (3) peserta didik kurang memiliki kemampuan dalam membaca grafik.

\section{SIMPULAN DAN SARAN}

Berdasarkan uraian pembahasan diatas dapat disimpulkan bahwa ada perbedaan yang signifikan pemahaman konseptual dan pemahaman grafik peserta didik yang dibelajarkan dengan schoology dalam model belajar learning cycle 6 fase-problem solving dengan peserta didik yang dibelajarkan dengan learning cycle 6 fase-problem solving pada materi laju reaksi.

Mengacu pada hasil penelitian yang telah dilakukan oleh peneliti, maka saran-saran yang perlu diperhatikan adalah sebagai berikut: (1) Perlu penelitian di beberapa sekolah yang memiliki kondisi serupa agar kesimpulan yang diperoleh dapat berlaku secara umum. (2) peneliti baru mengkaji pengaruh penggunaan schoology dalam model belajar learning cycle 6 fase-problem solving terhadap pemahaman konseptual dan pemahaman grafik peserta didik, variabel yang belum diteliti antara lain, motivasi peserta didik, kemampuan berpikir tingkat tinggi, dan retensi peserta didik. (3) bagi guru yang akan membelajarkan materi laju reaksi sebaiknya (a) lebih memperdalam konsepnya dengan memberikan latihan soal yang tidak hanya bisa dikerjakan dengan hafalan rumus saja, dan (b) memberikan bahan diskusi yang mengaitkan antara konsep kimia yang dipelajari di kelas dengan masalah yang berhubungan dengan kehidupan sehari-hari. (4) Apabila ada peneliti lain yang berminat untuk melakukan penelitian serupa, mohon hendaknya memperhatikan (a) sarana dan prasana yang tersedia di sekolah dan yang dimiliki peserta didik misalnya tersedianya laptop/komputer tiap peserta didik dan kemudahan akses internet, dan (b) mengorganisasi waktu dengan baik pada saat kegiatan online dan pada setiap fase yang dilaksanakan. (5) Penggunaan schoology dapat digunakan sebagai pembelajaran full online. 


\section{DAFTAR RUJUKAN}

Chang, R. 2004. Kimia Dasar Konsep-Konsep Inti Edisi Ketiga. Jakarta: Erlangga.

Chiu, M. H. 2001. Algorithmic Problem Solving and Conceptual Understanding of Chemistry by Students at A Local High School in Taiwan. Proceedings of The National Science Council, 11 (1): 20-38.

Costu, B. 2010. Algorithmic, Conceptual and Graphical Chemistry Problems: A Revisited Study. Asian $\begin{array}{lllll}\text { Journal of } & \text { Chemistry, } & \text { (Online), } & \text { (22): }\end{array}$ (http://www.yarbis1.yildiz.edu.tr/web/userPubFiles/bcostu_a1ce538bfa7a1ae1827caf26924 3ce00.pdf.), diakses 14 Februari 2013.

Creswell, J. W. 2002. Educational Reserch Planning, Conducting and Evaluating Quantitative and Qualitative Research Fourt Edition.USA: Pearson Education

Dziuban, C. D, Hartman, J. L, Moskal, P. D. 2004. Blended Learning.ECAR Research Buletin USA.

Effendy. 2008. A-Level Chemistry for Senior High School students Based on 2007 Cambridge Curriculum Volume 1A. Malang: Bayumedia Publishing.

Fajaroh, F. \& Dasna, I. W. 2004. Penggunaan Model Pembelajaran Learning Cycle untuk Meningkatkan Motivasi dan Hasil Belajar Kimia Zat Aditif dalam Bahan Makanan pada Siswa Kelas II SMU. Jurnal Pendidikan \& Pembelajaran, 11 (2): 112-122.

Iskandar, Srini M. 2011. Pendekatan Pembelajaran Sains Berbasis Konstruktivis. Malang: Bayumedia.

Kolomuc, A. \& Tekin, S. 2011. Cheemistry Teachers' Misconceptions Concerning Concept of Chemical reaction Rate.Eurasian Journal of Physics and Chemistry Education, (Online), 3 (2): 84-101, (http://www.eurasianjournals.com/index.php/ejpce), diakses 24 Januari 2013.

Nazriati \& Fajaroh, F. 2007. Pengaruh Penerapan Model learning Cycle dalam Pembelajaran Kimia Berbahan Ajar Terpadu (Makroskopis-Mikroskopis) terhadap Motivasi, Hasil Belajar, dan Retensi Kimia Siswa. Jurnal Pendidikan \& Pembelajaran, 14 (2): 168-182.

Rahayu, S., Prayitno, \& Fajaroh, F. 2008.Meningkatkan Kualitas Proses dan Hasil Belajar Kimia Dasar Mahasiswa Pendidikan Kimia UM dengan Strategi Learning Cycle-Cooperative-5E (LCC5E).Jurnal Pendidikan \& Pembelajaran, 14 (2): 124-136.

Staker, H. \& Horn, M. B. 2012.Classifying K-12 Blended learning. Innosight Institute. 